\title{
Lack of Inhibition of Intestinal Heme Oxygenase by Antibiotics and Tin-Protoporphyrin
}

\author{
SUSAN R. HINTZ, CHARLES B. KIM, HENDRIK J. VREMAN, AND DAVID K. STEVENSON \\ Department of Pediatrics, Stanford University School of Medicine, Stanford, California 94305
}

\begin{abstract}
We assessed the in vivo and in vitro effects of antibiotics and tin-protoporphyrin (TP) on intestinal heme oxygenase (HO) activity using a gas chromatographic assay. This method measures the carbon monoxide produced from heme in the presence of NADPH. After in vivo administration of kanamycin $(10 \mathrm{mg} / \mathrm{kg}$ body weight), ampicillin $(200 \mathrm{mg} / \mathrm{kg}$ body weight) or neomycin $(60 \mathrm{mg} /$ $\mathrm{kg}$ body weight) with or without TP $(65 \mu \mathrm{mol} / \mathrm{kg}$ body weight) to suckling rats, no significant difference in $\mathrm{HO}$ activity along the small intestine was observed. In vitro exposure of adult rat intestinal preparations to the antibiotics showed no significant decrease in $\mathrm{HO}$ activity between control and experimental tissue preparations. A concentration-dependent stimulatory effect of neomycin was observed. Subcutaneous administration of TP $(25 \mu \mathrm{mol} / \mathrm{kg}$ body weight) to adult male Wistar rats revealed no significant inhibition of the intestine. However, in vitro addition of TP $(12.5 \mu \mathrm{M})$ to the control tissue preparations of adult Wistar rats revealed highly significant inhibition in liver and spleen when compared to the unexposed control tissues. In contrast, when TP was added to control intestinal preparations no inhibition was observed. These findings suggest that suckling rat intestinal heme oxygenase is not inhibited by in vivo treatment with high concentrations of kanamycin, ampicillin, or neomycin. Furthermore, these antibiotics are not in vitro inhibitors of adult rat intestinal HO. Finally, adult rat intestinal HO is not inhibited either in vivo or in vitro by a concentration of $T P$ that significantly inhibits liver and spleen activity. (Pediatr Res 23: 50-53, 1988)
\end{abstract}

Abbreviations

CO, carbon monoxide

TP, tin-protoporphyrin

HO, heme oxygenase

$\mathrm{VeCO}$, excretion rate of $\mathrm{CO}$

TP, a synthetic heme analog, has been reported to be a competitive inhibitor of $\mathrm{HO}(1-3)$. This rate-limiting enzyme in the heme catabolic pathway (4) catalyzes the equimolar formation of bilirubin and CO. In vivo studies with TP have demonstrated the drug's effectiveness in lowering serum bilirubin levels in rats (5), in mice with severe hemolytic anemia (6) in rhesus monkeys (7), and in man (8). Preliminary studies in our laboratory suggested that a single dose of TP has no suppressive effect on the excretion rate of $\mathrm{CO}(\mathrm{VeCO})$ in suckling rats $(9,10)$ unless

Received July 15, 1987; accepted September 1, 1987

Reprint requests David K. Stevenson, M.D., Stanford University School of Medicine, Department of Pediatrics, S-222, Stanford, CA 94305.

Supported in part by Mead Johnson Nutritional Division, Christopher Taylor Harrison Research Fund and NIH Grant HD-14426. the animals are first treated with broad spectrum antibiotics (11). Later studies, showing that heme is excreted into the bile of TPtreated adult rats $(12,13)$ pointed to two possible explanations for the paradox: 1) heme-degrading bacteria in the intestine produced $\mathrm{CO}$ (14), thus preventing us from observing the inhibitory effects of TP until the bacteria were eradicated by antibiotics or 2) antibiotics directly inhibited intestinal HO. Because heme reaching the intestine can be catabolized to bilirubin and $\mathrm{CO}$ by intestinal tissue $\mathrm{HO}(15)$, the question of inhibition of intestinal HO has potential clinical importance. In the present study, we assessed the in vivo and in vitro effect of antibiotics and TP on intestinal $\mathrm{HO}$ activity, using a gas chromatographic assay for measuring $\mathrm{HO}$ activity through the $\mathrm{CO}$ produced from heme in the presence of NADPH $(16,17)$.

\section{MATERIALS AND METHODS}

Animals. Wistar rats were used for all experiments. For neonate studies, litters of rats were received within $12 \mathrm{~h}$ postpartum. The average weight of the suckling rats was $6.25 \mathrm{~g}$. Adult males of 250-300 g each were used for adult experiments. Neonates were allowed free access to their mother between treatments and adults were fed MRH 22/5 Rodent Blox (Wayne Animal Diets, Chicago, IL) and water ad libitum. All animals were housed in a temperature-controlled room $\left(24 \pm 1^{\circ} \mathrm{C}\right)$ with a 12 -h light cycle. All animals were sacrificed by decapitation.

$T P$. TP was purchased from Porphyrin Products Inc. (Logan, UT), and was prepared as described previously (11), stored in the dark and used within $1 \mathrm{~h}$ of preparation.

Methemalbumin. Two concentrations of methemalbumin were used for these experiments. A 2.0/0.15 mM concentration was used for in vivo antibiotic-treated suckling $\mathrm{HO}$ determinations (Table 1). Thirteen mg of hemin (Sigma Chemical Co., St. Louis, MO) were dissolved in $2.5 \mathrm{ml} 0.4 \mathrm{M} \mathrm{Na}_{3} \mathrm{PO}_{4}$. Distilled water $(6.5 \mathrm{ml})$ and $100 \mathrm{mg}$ bovine serum albumin (Sigma) were added. The solution was gradually titrated to $\mathrm{pH} 7.4$ with $10 \mathrm{~N}$ $\mathrm{HCl}$ under stirring. The volume was adjusted to $10 \mathrm{ml}$ with distilled water and stored at $4^{\circ} \mathrm{C}$ for up to 1 month. A dilute $(150 / 11.2 \mu \mathrm{M})$ methemalbumin solution was used for studies assessing in vitro antibiotic treatment of adult intestinal homogenates (Table 3 ) and in vivo and in vitro TP treatment of adult rats (Table 2). This solution was prepared by diluting the solution described above with $0.1 \mathrm{M} \mathrm{KPO}_{4}, \mathrm{pH} 7.4$ (buffer).

NADPH. NADPH (4.0 mg), tetrasodium salt, $8.5 \%$ water, type

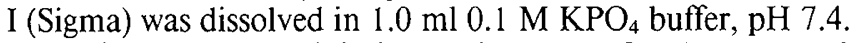

Antibiotics. The antibiotic solutions used for the in vitro incubations with adult rat tissue supernatants were prepared as follows. Twenty-five times concentrated solutions were made by dissolving $100 \mathrm{mg}$ neomycin sulfate (The Upjohn Company, Kalamazoo, MI), $21.2 \mathrm{mg}$ ampicillin sodium (Wyeth Laboratories, Philadelphia, PA), and $1.0 \mathrm{mg}$ kanamycin sulfate (Beecham Laboratories, Bristol, TN) per ml of $0.1 \mathrm{M} \mathrm{KPO}_{4}$ buffer, pH 7.4. These solutions were further diluted to $5 \times$ and $1 \times$ with the appropriate amount of buffer. Twenty $\mu$ l of these solutions were 
added to the reaction vials yielding final reaction medium concentrations (for the $25 \times$ solutions) of $25.0 \mathrm{mg}$ neomycin $/ \mathrm{ml}$, $5.03 \mathrm{mg}$ ampicillin $/ \mathrm{ml}$, and $0.25 \mathrm{mg} \mathrm{kanamycin} / \mathrm{ml}$. The antibiotics for the in vivo treatment of sucklings were similarly prepared in the following concentrations: $1.5 \mathrm{mg}$ neomycin $/ \mathrm{ml}$, $250 \mathrm{mg}$ ampicillin $/ \mathrm{ml}$, and $12.5 \mathrm{mg} \mathrm{kanamycin} / \mathrm{ml}$.

Tissue collection and preparation. Tissue supernatants were prepared for assay as follows.

Liver and Spleen. The organs were removed and washed with ice-cold buffer. Each organ was homogenized with a Biohomogenizer (Biospec Products, Inc, Bartlesville, OK) in 4 volumes of buffer and the preparations were centrifuged at $13,000 \times g$ for $15 \mathrm{~min}$. The supernatant was then analyzed.

Adult Intestine. The entire intestinal length was perfused with $20 \mathrm{ml}$ of ice-cold buffer to remove the content. The intestine was then cut longitudinally into two equal sections. The mucosa was collected from one of the sections by gently scraping the tissue with a glass slide. The serosa was designated as what remained of the first section after the mucosa was removed. The second section was left intact and was referred to as "whole" in Tables 2 and 3 . The three intestinal fractions were homogenized in 4 volumes of buffer and centrifuged as described above.

Neonate Intestine. After removal of the small intestine, the entire length was perfused with $5-\mathrm{ml}$ of ice cold buffer. Three sections of $3 \mathrm{~cm}$ each were excised corresponding to the duodenum, jejunum, and ileum. Due to the fragile nature of the intestine, the mucosa could not be collected in the same manner as for the adult tissues. Instead, the intestinal segments were simply homogenized in 4 volumes of buffer and centrifuged as described above.

$H O$ assay. Traditionally, in vitro $\mathrm{HO}$ activity is determined using a spectrophotometric method that measures bilirubin production (4). However, for this study, we used a gas chromatographic assay that measures the amount of $\mathrm{CO}$ produced from methemalbumin in the presence of NADPH (16-18). The procedure is a simplification of the method of Sunderman et al. (19). Twenty $\mu \mathrm{l}$ of the tissue preparation, $20 \mu \mathrm{l}$ of the appropriate methemalbumin solution, and either $20 \mu \mathrm{l}$ of NADPH (total) or buffer (blank) were placed in septum-sealed vials. For some studies, either antibiotics $(20 \mu \mathrm{l})$ or TP $(1.5 \mu \mathrm{l})$ was also added to vial. After a 5-min temperature equilibration, the vials were purged with CO-free air and allowed to incubate for $15 \mathrm{~min}$ at $37^{\circ} \mathrm{C}$. The reaction was terminated by quick freezing the vials in a dry ice/acetone bath $\left(-78^{\circ} \mathrm{C}\right)$. The $\mathrm{CO}$ produced in the vials was then quantified by a gas chromatograph coupled to a Reduction Gas Detector (Trace Analytical Inc., Menlo Park, CA) with a sensitivity of $1 \mathrm{pmol} / \mathrm{CO}$ vial $(18,20)$. CO production by total and blank, analyzed in duplicate, was calculated and $\mathrm{HO}$ activity is presented as the difference between total and blank reactions expressed as nmoles $\mathrm{CO}$ produced/h/mg protein.

As mentioned above, two concentrations of methemalbumin were used. Preliminary studies in our laboratory show that, due to competition, the effects of inhibitors such as TP may be reduced if the originally recommended (18) 2.0/0.15 mM methemalbumin solution is used for the assay. Inhibition is more clearly revealed when the less concentrated $150 / 11.2 \mu \mathrm{M}$ solution is utilized.

Protein determination. The supernatant protein concentration was determined by the method of Lowry et al. (21). Bovine serum albumin (Sigma) was used as the standard.

Experimental procedure. In Vivo Antibiotic Treatment of Sucklings (Table I). Upon arrival, Wistar rat litters were divided into three groups: saline-treated, antibiotic-treated, and TP + antibiotic treated. The treatment schedule closely followed that described by Posselt et al. (11). Antibiotic-treated and TP + antibiotic-treated pups were injected intramuscularly with $5 \mu \mathrm{l}$ each of kanamycin sulfate $(10 \mathrm{mg} / \mathrm{kg}$ body weight $)$ and ampicillin sodium $(200 \mathrm{mg} / \mathrm{kg}$ body weight $)$ at $\mathrm{t}=0,16,26$, and $42 \mathrm{~h}$. They were gavaged via Silastic tubing $(0.064 \times 0.030 \mathrm{~cm} \mathrm{ID,}$ Dow Corning Corporation, Midland, MI) with $0.25 \mathrm{ml}$ neomycin sulfate $(60 \mathrm{mg} / \mathrm{kg}$ body weight) at $\mathrm{t}=26$ and $42 \mathrm{~h}$. The salinetreated pups were injected and gavaged similarly with $0.9 \% \mathrm{NaCl}$. The TP + antibiotic-treated group also received a single subcutaneous injection of $40 \mu \mathrm{l}$ of TP $(65 \mu \mathrm{mol} / \mathrm{kg})$ at $\mathrm{t}=0 \mathrm{~h}$. The rats were sacrificed at $\mathrm{t}=48 \mathrm{~h}$, when Posselt et al. (11) observed the greatest difference between the $\mathrm{CO}$ excretion rats of TPtreated and saline-treated pups.

In Vitro Antibiotic Studies of Adult Rat Tissues (Table 2). Mucosal, serosal, and whole intestinal supernatants were obtained as described above from untreated adult Wistar rats. Heme oxygenase activity determinations were carried out as described above with $20 \mu$ lof the appropriate antibiotic solution added to the reaction vial. The activities were compared with controls in which $20 \mu \mathrm{l}$ buffer had been added to the reaction vial in place of the antibiotics.

In Vivo TP Treatment of Adult Rats (Table 3). Adult male Wistar rats were injected subcutaneously with either $25 \mu \mathrm{mol}$ $\mathrm{TP} / \mathrm{kg}$ body weight (TP) or an equal volume of saline (control) at $\mathrm{t}=0 \mathrm{~h}$. Rats were sacrificed at $\mathrm{t}=16 \mathrm{~h}$ and tissue preparation was carried out as described above.

In Vitro TP Treatment of Adult Rat Tissues (Table 3). Tissue preparations from control rats were used for these in vitro studies of $\mathrm{HO}$ activity; $1.5 \mu \mathrm{l}$ of a $0.5 \mathrm{mM}$ TP solution were added to reaction vials containing supernatant, methemalbumin, and either buffer or NADPH. Heme oxygenase determinations were performed as described above.

Statistics. All values are expressed as mean \pm SD. Student's $t$ test for independent and paired samples was used for statistical analysis of results.

\section{RESULTS}

After in vivo treatment of suckling rats (Table 1), no significant difference in $\mathrm{HO}$ activity in any segment of the intestine was observed between the three treatment groups (saline control, antibiotics, and TP + antibiotics). The activity gradient observed for the control group was maintained after the treatments. In vitro treatment of adult rat intestine preparations with neomycin, ampicillin, and kanamycin (Table 2) showed no significant decrease in $\mathrm{HO}$ activity between control and treated groups. A concentration-dependent stimulation of $\mathrm{HO}$ activity in both mucosa and whole intestine was observed after addition of neomycin. No significant inhibition of the adult rat intestine was observed after either in vivo subcutaneous treatment with TP or in vitro exposure to TP (Table 3). However, adult rat liver $\mathrm{HO}$ activity was significantly inhibited after in vivo treatment with the same concentration, and both spleen and liver $\mathrm{HO}$ activities were significantly inhibited after in vitro exposure to the drug.

\section{DISCUSSION}

After in vitro addition of neomycin, ampicillin, and kanamycin to adult rat intestine preparations, no suppression of $\mathrm{HO}$ activity is observed. Our data also suggest that these antibiotics are not in vivo inhibitors of the suckling rat intestine. Posselt et al. (11)

Table 1. HO activity in suckling rat intestine supernatants after in vivo treatment with broad-spectrum antibiotics or antibiotics and $65 \mu \mathrm{mol} \mathrm{TP} / \mathrm{kg}$ body $\mathrm{wt}^{*}$

\begin{tabular}{lccc}
\hline & \multicolumn{3}{c}{ HO activity (mean $\pm \mathrm{SD}, \mathrm{nmol} / \mathrm{h} /$} \\
& mg protein) \\
\cline { 2 - 4 } & Duodenum & Jejunum & Ileum \\
\hline Saline $(n=6)$ & $1.7 \pm 0.9$ & $2.8 \pm 0.9$ & $3.5 \pm 0.9$ \\
Antibiotics $(n=9)$ & $1.5 \pm 0.3$ & $2.1 \pm 0.6$ & $3.0 \pm 0.9$ \\
Antibiotics $+\mathrm{TP}(n=9)$ & $1.5 \pm 0.4$ & $2.4 \pm 0.6$ & $3.0 \pm 1.0$ \\
\hline
\end{tabular}

* This study was performed using the $2.0 / 0.15 \mathrm{mM}$ methemalbumin solution. No significant difference existed between treatment groups within each intestinal segment. 
Table 2. HO activity of adult rat intestinal tissue $13,000 \times \mathrm{g}$ supernatants in the presence of various concentrations of three antibiotics*

\begin{tabular}{|c|c|c|c|c|}
\hline & \multicolumn{4}{|c|}{$\mathrm{HO}$ activity (mean $\pm \mathrm{SD}, \mathrm{nmol} \mathrm{CO} / \mathrm{h} / \mathrm{mg}$ protein) } \\
\hline & Control & $1 \times$ & $5 \times$ & $25 \times$ \\
\hline \multicolumn{5}{|l|}{ Neomycin } \\
\hline Whole $(n=3)$ & $0.37 \pm 0.18$ & $0.58 \pm 0.12$ & $1.00 \pm 0.08 \ddagger$ & $1.66 \pm 0.28 \ddagger$ \\
\hline \multicolumn{5}{|l|}{ Ampicillin } \\
\hline Mucosa $(n=3)$ & $0.58 \pm 0.31$ & ND§ & ND & $0.73 \pm 0.43$ \\
\hline \multicolumn{5}{|l|}{ Kanamycin } \\
\hline $\operatorname{Mucosa}(n=3)$ & $0.58 \pm 0.31$ & ND & ND & $0.58 \pm 0.36$ \\
\hline Whole $(n=3)$ & $0.37 \pm 0.18$ & ND & ND & $0.37 \pm 0.13$ \\
\hline
\end{tabular}

* The control contained no antibiotics. Antibiotic concentrations are described in "Materials and methods." This study was performed using the $150 / 11.2 \mu \mathrm{M}$ methemalbumin solution. Unmarked values were not significantly different from control.

$\dagger p<0.05$ compared to control.

$\ddagger p<0.01$ compared to control.

$\S$ Not determined.

Table 3. HO activity of various tissue $13,000 \times g$ supernatants from adult male Wistar rats after $16 \mathrm{~h}$ of in vivo exposure to saline (control) or 25 mole TP/kg body wt (TP)*

\begin{tabular}{lccc}
\hline & \multicolumn{3}{c}{ HO activity $\begin{array}{c}\text { (mean } \pm \mathrm{SD}, \mathrm{nmol} \mathrm{CO} / \mathrm{h} / \mathrm{mg} \\
\text { protein) }\end{array}$} \\
\cline { 2 - 4 } & Control & \multicolumn{1}{c}{ TP } & Control $+\mathrm{TP}$ \\
\hline Liver $(n=6)$ & $0.31 \pm 0.13$ & $0.15 \pm 0.04 \dagger$ & $0.08 \pm 0.07 \ddagger$ \\
Spleen $(n=6)$ & $1.09 \pm 0.15$ & $0.95 \pm 0.23$ & $0.10 \pm 0.10 \S$ \\
Whole IT $(n=5)$ & $0.27 \pm 0.10$ & $0.31 \pm 0.20$ & $0.32 \pm 0.14$ \\
Mucosa $(n=5)$ & $0.30 \pm 0.15$ & $0.33 \pm 0.28$ & $0.31 \pm 0.28$ \\
Serosa $(n=6)$ & $0.20 \pm 0.05$ & $0.22 \pm 0.12$ & $0.19 \pm 0.06$ \\
\hline
\end{tabular}

* The last column (control $+\mathrm{TP}$ ) lists HO activity of control tissues incubated in vitro with $12.5 \mu \mathrm{M}$ TP. This study was performed using the $150 / 11.2 \mu \mathrm{M}$ methemalbumin solution. Unmarked values were not significantly different from control.

$\dagger p<0.05$ compared to control.

$\ddagger p<0.01$ compared to control.

$\S p<0.001$ compared to control.

were only able to demonstrate inhibitory effect of TP, as measured by the $\mathrm{VeCO}$, by first treating suckling Wistar rats with broad-spectrum antibiotics. Because undegraded heme is excreted into the intestine with the bile $(12,13)$, two explanations were offered for the observed phenomenon. 1) The antibiotics had eradicated the heme-degrading, CO-producing bacteria (14) in the gut or 2) the antibiotics had directly inhibited intestinal HO. The present study, however, eliminates the possibility of intestinal $\mathrm{HO}$ inhibition by antibiotics. By their negative findings, both the in vivo and in vitro studies point to the reduction of aerobic bacterial colonization in the gut as the cause of the decrease in $\mathrm{CO}$ excretion after TP treatment of the animals receiving broad-spectrum antibiotics to suppress and/or eradicate their colonization. It appears that the use of antibiotics in the study by Posselt et al. (11) simply "unmasked" the inhibition by $\mathrm{TP}$ of $\mathrm{HO}$ in other organs such as the liver.

An unexpected interesting finding is that adult rat intestinal $\mathrm{HO}$ is not inhibited either in vivo or in vitro at a concentration of TP that significantly inhibits liver and spleen $\mathrm{HO}$ activity. Although the lack of inhibition of intestinal $\mathrm{HO}$ in the in vivo studies (9) taken by themselves might be explained by the fact that the TP concentration could be low when compared with other tissues, such as the liver, the lack of in vitro inhibition, requires another explanation. Maines et al. (22) have offered evidence for two forms of $\mathrm{HO}$. The possibility exists that there is yet another form of $\mathrm{HO}$, peculiar to the intestinal mucosa cells, which is not inhibitable by TP. The design of the previous studies by our laboratory showing decreased $\mathrm{CO}$ excretion after TP treatment in animals that had prophylactically received broad-spectrum antibiotics did not exclude some measurable contribution to the $\mathrm{VeCO}$ by intestinal $\mathrm{HO}$ degradation of heme, reaching the intestine via the bile $(12,13)$. However, the fact that the suppression of $\mathrm{CO}$ excretion could be appreciated only after antibiotics suggests that bacterial breakdown of heme was an important source of $\mathrm{CO}$ in animals not treated with antibiotics. This might be further interpreted as suggesting that a comparable amount of heme was not absorbed by the intestine, precluding intestinal heme oxygenase breakdown of heme. The possibility of heme breakdown by intestinal $\mathrm{HO}$ is important to consider because intestinal $\mathrm{CO}$ production from biliary heme could be coupled with bilirubin production by the $\mathrm{HO}$ in intestinal mucosal cells. This bilirubin could be absorbed into the circulation, thereby compromising the efficacy of TP for reducing serum bilirubin levels in neonates.

Because intestinal $\mathrm{HO}$ appears to be different in terms of its vulnerability to competitive inhibition by TP compared to the $\mathrm{HO}$ present in other tissues, we suggest that the disposition of biliary heme be carefully evaluated, especially in appropriate neonatal models, where the enterohepatic circulation is prominent in the transitional period after birth. Although even lower concentrations of TP than those used in these experiments may be effective at inhibiting $\mathrm{HO}$ in other tissues, such as the liver, heme diverted to the intestine could be degraded to $\mathrm{CO}$ and bilirubin because of the lack of $\mathrm{HO}$ inhibition in this tissue. In light of the presented results, oral administration of TP would not be an effective solution. The enteral route, however, with direct intestinal absorption of $\mathrm{TP}$, might still represent a feasible option for achieving effective inhibitory concentrations of TP in other sensitive organs.

\section{REFERENCES}

1. Drummond GS, Kappas A 1981 Prevention of neonatal hyperbilirubinemia by tin-protoporphyrin IX, a potent competitive inhibitor of heme oxidation. Proc Natl Acad Sci USA 78:6466-6470

2. Yoshinaga T, Sassa S, Kappas A 1982 Purification and properties of bovine spleen heme oxygenase. Amino acid composition and sites of action of inhibitors of heme oxidation. J Biol Chem 257:7778-7785

3. Maines MD 1981 Zinc-protoporphyrin is a selective inhibitor of heme oxygenase activity in the neonatal rat. Biochem Biophys Acta 673:339-350

4. Tenhunen R, Marver HS, Schmid R 1968 The enzymatic conversion of heme to bilirubin by microsomal heme oxygenase. Proc Natl Acad Sci USA 61:748-755

5. Kappas A, Drummond GS, Simionatto CS, Anderson KE 1984 Control of 
heme oxygenase and plasma levels of bilirubin by a synthetic heme analog, tin-protoporphyrin. Hepatology 4:336-341

6. Sassa A, Drummond GS, Bernstein SE, Kappas A 1983 Tin-protoporphyrin suppression of hyperbilirubinemia in mutant mice with severe hemolytic anemia. Blood 61:1011-1013

7. Cornelius CE, Rodgers PA 1984 Prevention of neonatal hyperbilirubinemia in rhesus monkeys by tin-protoporphyrin. Pediatr Res 18:728-738

8. Anderson KE, Simionatto CS, Drummond GS, Kappas A 1986 Disposition of tin-protoporphyrin and suppression of hyperbilirubinemia in humans. Clin Pharmacol Ther 39:510-520

9. Cowan BE, Kwong LK, Vreman HJ, Stevenson DK 1983 The effect of tinprotoporphyrin on the bilirubin production rate in newborn rats. Pediatr Pharmacol 3:95-100

10. Posselt AM, Cowan BE, Kwong LK, Vreman HJ, Stevenson DK 1985 Effect of tin-protoporphyrin on the excretion rate of carbon monoxide in newborn rats after hematoma formation. J Pediatr 4:650-654

11. Posselt AM, Kwong LK, Vreman HJ, Stevenson DK 1986 Suppression of carbon monoxide excretion rate by tin-protoporphyrin. Am J Dis Child 140:147-150

12. Kappas A, Simionatto CS, Drummond GS, Sassa S, Anderson KE 1985 The liver excretes large amounts of heme into bile when heme oxygenase is inhibited competitively by Sn-protoporphyrin. Proc Natl Acad Sci USA 82:890-900

13. Hintz SR, Kwong LK, Vreman HJ, Stevenson DK 1987 Recovery of exogenous heme as carbon monoxide and biliary heme in adult rats after tin-protoporphyrin. J Pediatr Gastroenterol Nutr 6:302-306

14. Engel RB, Matsen JM, Chapman SS, Schwartz S 1972 Carbon monoxide production from heme compounds by bacteria. J Bacteriol 112:1310-1315

15. Correia MA, Schmid R 1975 Effect of cobalt on microsomal cytochrome P450: differences between liver and intestinal mucosa. Biochem Biophys Res Commun 65:1378-1384

16. Vreman HJ, Stevenson DK 1987 Direct measurement of heme oxygenase activity by gas chromatography. Pediatr Res $21: 242 \mathrm{~A}$ (abstr)

17. Kim CB, Hintz SR, Vreman HJ, Kwong LK, Stevenson DK In vitro carbon monoxide production by the small intestine of suckling and adult Wistar rats: effect of parenteral tin-protoporphyrin. Dev Pharmacol Ther (in press)

18. Vreman HJ, Stevenson DK Heme oxygenase activity as measured by carbon monoxide production. Anal Biochem (in press)

19. Sunderman Jr. FW, Downs JR, Reid MC, Bibeau LM 1982 Gas chromatographic assay for heme oxygenase activity. Clin Chem 28/10:2026-2032

20. Vreman HJ, Kwong LK, Stevenson DK 1984 Carbon monoxide in blood: an improved micro-blood sample collection system with rapid analysis by gas chromatography. Clin Chem 30:1382-1386

21. Lowry OH, Roseborough HJ, Fan AL, Randall RJ 1951 Protein measurement with the Folin reagent. J Bio Chem 193:264-275

22. Maines MD, Trakshel GM, Kutty RK 1986 Characterization of two constitutive forms of rat liver microsomal heme oxygenase: only one molecular species of the enzyme is inducible. J Biol Chem 261:411-419 